\title{
The distribution of snow accumulation across the Austfonna ice cap, Svalbard: direct measurements and modelling
}

\author{
Andrea Taurisano, ${ }^{1}$ Thomas V. Schuler, ${ }^{2}$ Jon Ove Hagen, ${ }^{2}$ Trond Eiken, ${ }^{2}$ Even Loe, ${ }^{2}$ Kjetil Melvold ${ }^{3}$ \& Jack Kohler ${ }^{1}$ \\ 1 Norwegian Polar Institute, Polar Environmental Centre, Norway \\ 2 Deptartment of Geosciences, University of Oslo, Box 1047, Blindern, NO-0316 Oslo, Norway \\ 3 Norwegian Water Resources and Energy Directorate, Box 5091, Majorstua, NO-0301 Oslo, Norway
}

\begin{abstract}
Keywords
Snow accumulation; mass balance; GPR; modelling

\section{Correspondence}

Andrea Taurisano, Multiconsult AS, Fiolvegen

13, 9016, Tromsø, Norway. Email:

andrea.taurisano@multiconsult.no
\end{abstract}

doi:10.1111/j.1751-8369.2007.00004.x

\begin{abstract}
We present an analysis of the spatial variability in the snow accumulation on the Austfonna ice cap in Svalbard, Norway, based on the results of field investigations conducted in the spring of 1999, 2004 and 2005. During the campaigns ground penetrating radar measurements at 500 and $800 \mathrm{MHz}$ were collected along profiles, along with additional manual snow sounding and pit stratigraphy work. The analysis of the data reveals a consistent pattern in the spatial distribution of the snow accumulation over the ice-cap, and therefore enables the compilation of a multiple regression model of the snow distribution across the ice cap. Once validated, the results of the model complement the information derived from direct measurements, with an accumulation index for every point on the ice cap, thus enhancing the accuracy of future mass balance studies and dynamic modelling of Austfonna. As very few direct meteorological measurements are performed in the eastern part of Svalbard, the accumulation measurements on the Austfonna ice cap provide valuable integrated information about winter precipitation in this region.
\end{abstract}

Centred at $79.7^{\circ} \mathrm{N}, 24.0^{\circ} \mathrm{E}$, the Austfonna ice cap stretches out over much of Nordaustlandet, the northeastern island of the Svalbard archipelago, and with an area of $8120 \mathrm{~km}^{2}$ it is the largest ice cap in the European Arctic. The ice cap has a maximum elevation of $809 \mathrm{~m}$ a.s.l., a thickness of up to ca. $560 \mathrm{~m}$ (Dowdeswell et al. 1986) and a relatively simple geometry, characterized by one main dome feeding a number of drainage basins. There is evidence that the dynamic regime differs between individual basins, and some of them are known to be of the surge type (Dowdeswell 1986).

The scientific exploration of Austfonna started with the first crossing by A. E. Nordenskjold in 1873. New traverses were completed by the Oxford expedition in 1924 (Binney 1925), H. W. Ahlmann in 1931 (Ahlmann 1933 ) and V. Schytt during the International Geophysical Year 1957/58 (Schytt 1964). More recently, glaciological and geophysical investigations were carried out by J. A. Dowdeswell in the 1980s (Dowdeswell \& Drewry 1989). These included a radar-based mapping of the ice surface and bedrock topography, and the earliest ground-based measurements of mass balance and ice velocity. Recently, airborne laser altimetry, first conducted in 1996 and repeated in 2002, indicated an elevation increase in the central parts of the ice cap and lowering towards the margins (Bamber et al. 2004). Although work has started to assess the contribution of surface mass balance (Schuler et al. in press), there is still considerable uncertainty about the present state of balance of Austfonna and how it may respond to climate change.

In the mid 1980s deep ice cores were retrieved from Austfonna by Russian investigators (Punning et al. 1986; Zagorodnov \& Arkhipov 1990), and new cores from down to 118 and $288 \mathrm{~m}$ were obtained by Japanese teams in 1998 and 1999, respectively (Watanabe et al. 2000). During the same two years, 29 shallow cores were drilled by Norwegian researchers to investigate the accumulation pattern on Austfonna (Melvold et al. 1999). Furthermore, this work was complemented with a number of ground penetrating radar (GPR) profiles and provided a first insight to the spatial distribution of the accumulation (Pinglot et al. 2001). The authors found a north-westsouth-east gradient in the snow accumulation for the winter of 1998/99, which suggested that the northeastern location of Austfonna in the Svalbard archipelago is likely to make Austfonna more directly influenced by 
atmospheric systems from the Barents Sea region than by westerly systems.

This observation suggests that meteorological records from the automatic stations situated on Spitsbergen are not representative of the weather conditions on the ice cap, and can not be reliably used as input data for either mass balance reconstructions or glaciological models. Therefore, it is essential to collect information on the snow accumulation distribution and the recent temporal variability from the Austfonna glacier itself. This is also relevant in light of the fact that still too little is known about the present mass balance of Austfonna.

The aim of this work is to present the results of groundbased measurements of snow accumulation repeated on Austfonna in the spring of 1999, 2004 and 2005 by using a combination of GPR, direct snow sounding and snowpit work. A multiple regression model is also presented for the snow distribution across the ice cap. We develop a diagnostic model of snow distribution based on these data. Hence we do not intend to make temporal predictions (e.g. future evolution), but do intend to achieve a spatially consistent (i.e. no gaps) description of our observations.

\section{Data and methods}

GPR and global positioning system (GPS) profiles were collected on Austfonna, at the end of April 1999, 2004 and 2005 (Fig. 1), in a time window during which the winter snow pack is believed to be of maximum thickness before the onset of melting. For the geophysical investigations, a RAMAC impulse radar (Malà Geoscience, Malà, Sweden) operating at $500 \mathrm{MHz}$ was used in 1999, whereas an 800-MHz antenna was utilized in 2004 and 2005. In 1999, each radar file was collected in the form of 512 samples with a sampling frequency of $4865 \mathrm{MHz}$, giving a time window of 105 ns for each trace. In 2004 and 2005, the radar was operated with 1024 samples with a sampling frequency of $8099 \mathrm{MHz}$, and a corresponding time window of 126 ns. For each campaign, the radar control unit, a laptop, a GPS receiver and a tripodmounted GPS antenna were installed in a sledge pulled by a snowmobile, while the radar antenna was placed in a pulka sledge gliding about $2 \mathrm{~m}$ behind the first sledge. The radar was operated in Time Mode with a time interval of $0.5 \mathrm{~s}$, which corresponds to ca. $2 \mathrm{~m}$ when driving at a speed of $4 \mathrm{~m} \mathrm{~s}^{-1}$. The GPS mounted on the sledge, a Javad Positioning Systems dual frequency GPS (Javad Navigation Systems, San Jose, CA, USA) with Glonass receiver (Www.glonass-ianc.rsa.ru), was used as a rover for the kinematic survey of the profiles, whereas an analogous receiver collected static observations at the camp site on the glacier summit. All GPS observations from this reference receiver were in turn referred to those collected at a fixed geodetic point situated on a hill ca. $45 \mathrm{~km}$ west of the summit. Further details of this method are described by Eiken et al. (1997).

Snow thickness profiles are obtained from the radar files by digitizing the reflector that corresponds to the surfaces of the previous summer, i.e. the snow-ice transition in the ablation area and the snow-firn interface in the accumulation area. These transitions are revealed on the radar profiles by the first continuous reflector, whereas occasional ice layers within the snow pack appear as shorter lower amplitude reflectors and are better detected when using the higher resolution $800-\mathrm{MHz}$ antenna. The digitalization was performed manually, as the accuracy of the automatic picking routine is greatly affected by the dielectric constant contrast between the snow and the underlying firn or ice, and a number of other factors described by Pinglot et al. (2001), the most important being the roughness of the interface and interferences from nearby reflectors. At some places the heterogeneous dielectric properties of the firn made it especially problematic to digitize the summer surface in the accumulation area. In these cases, it proved beneficial to calibrate the GPR profile using manual snow depth soundings, which were collected at $2-\mathrm{km}$ intervals along the profiles. These were additionally backed up by digging pits down to the base of the winter snow pack. The GPS measurements finally allowed us to geo-code both manual soundings and radar profiles.

\section{Analysis and results}

Over $250 \mathrm{~km}$ of radar profiles were collected both in 1999 and 2004, whereas bad weather limited the data collection in 2005 to only ca. $150 \mathrm{~km}$ of profiles. All profiles measured along the south-west-north-east and northwest-south-east transects were repeated with the spatial accuracy of a few metres typically allowed by GPS navigation. The GPR measurements performed along the north-south traverse in 2004 and (partly) in 2005 do not overlap with the ones from 1999, but run roughly parallel ca. $2 \mathrm{~km}$ east of them. The reason for this is that the latest investigations were concentrated along two of the future CryoSat orbit tracks, where airborne geophysical measurements were also being carried out as part of the international CryoSat calibration and validation effort. The limited overlay of the measurements conducted in different campaigns influences the type of data analysis used.

In Fig. 2 we present snow thickness profiles derived from three years of radar investigations along the (a) north-west-south-east and (b) south-west-north-east transects on Austfonna. A consistent east-west gradient 
Figure 1 Location map of Nordaustlandet (inset map shows Svalbard) showing the tracks of the profiles measured in 1999, 2004 and 2005 (thick lines). The thin lines indicate profiles measured in 1999 only, whereas the white dots mark manual soundings of the snow thickness.

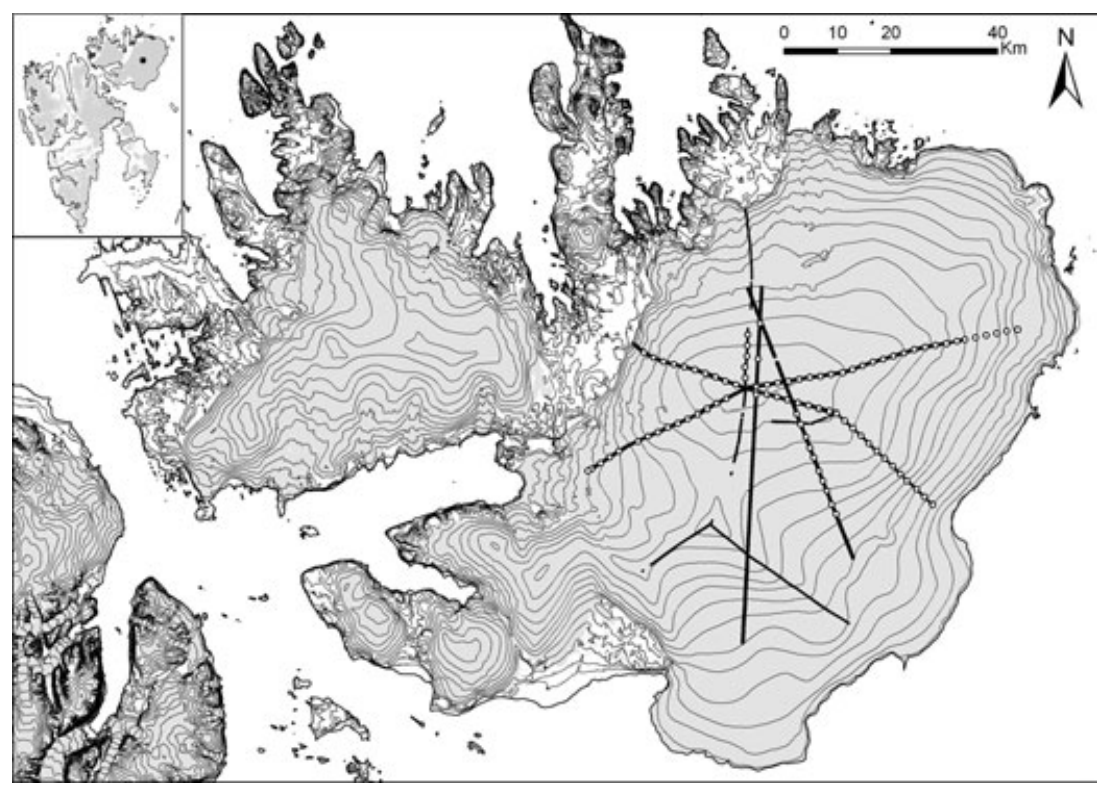

in snow accumulation is found, with snow depths on the east side of the ice cap being at least double the snow depths on the west side, as suggested by Pinglot et al. (2001).

The full datasets of snow thickness for the three years 1999, 2004 and 2005 are presented in Fig. 3. Intercomparison of the individual datasets shows a considerable year-to-year variability of snow thickness, with significantly less snow in 2004 than in the other two years (compare also Fig. 2). Closer inspection of the spatial distribution of the snow thickness data reveals an accumulation gradient from the highest values found in the south-east part of the ice cap to the considerably lower values found in the north-west (Fig. 3). In all three years, snow accumulation in the south-east part was about three times larger than that in the north-west. This general pattern was recognized by Schytt (1964) and more recently by Pinglot et al. (2001), who used spatial interpolation techniques to investigate the snow distribution based on the 1999 dataset. However, the methodology used in their analysis describes snow thickness at each location only as a function of distance to the surrounding data points, and hence can be regarded as a data interpolator. Here, instead, we aim to develop a parameterization of the snow distribution that can describe the accumulation pattern at every point of the ice cap. Such a parameterization could be used in a model of the surface mass balance, requiring a spatially complete accumulation scheme that can be driven by external (e.g. meteorological) data.

In previous studies, snow accumulation was often distributed over the domain using a linear lapse rate with elevation (e.g. Schuler et al. 2002, 2005), an approach that is appropriate on valley glaciers. However, scatter plots of snow thickness data versus elevation across the Austfonna ice cap (Fig. 4a) exhibit two clearly separated branches, which shows that a single elevation gradient is not appropriate to describe the data.

Investigating the relationships between snow thickness and the other spatial coordinates reveals that the snow thickness is most closely correlated to the $x$ coordinate (Fig. 4b), whereas the relationship to the $y$ coordinate (Fig. 4c) shows a more complex pattern. In summary, the data reveals a pronounced south-east-north-west component in the snow distribution, with the east-west component being larger than the south-north component. Additionally, an elevation gradient is superimposed on this trend. The bell-shaped distribution in Fig. 4a suggests different linear elevation gradients for different expositions of the ice cap.

We aim to describe this distribution by adopting a gradient in the horizontal plane with a vertical gradient superimposed on it. The same approach has been used previously by Aðalgeirsdóttir et al. (2003) to parameterize the mass balance across the Vatnajökull ice cap. The gradients in our snow distribution can thus be determined using a multiple regression approach that relates the snow thickness to all three spatial coordinates. This approach better describes the snow thickness at each location (Fig. 4d). The functional relationship takes the form

$$
s=a_{0}+a_{1} x+a_{2} y+a_{3} z
$$

where the terms $x, y$ and $z$ are the spatial coordinates (in metres), $s$ denotes the snow thickness (in metres) 


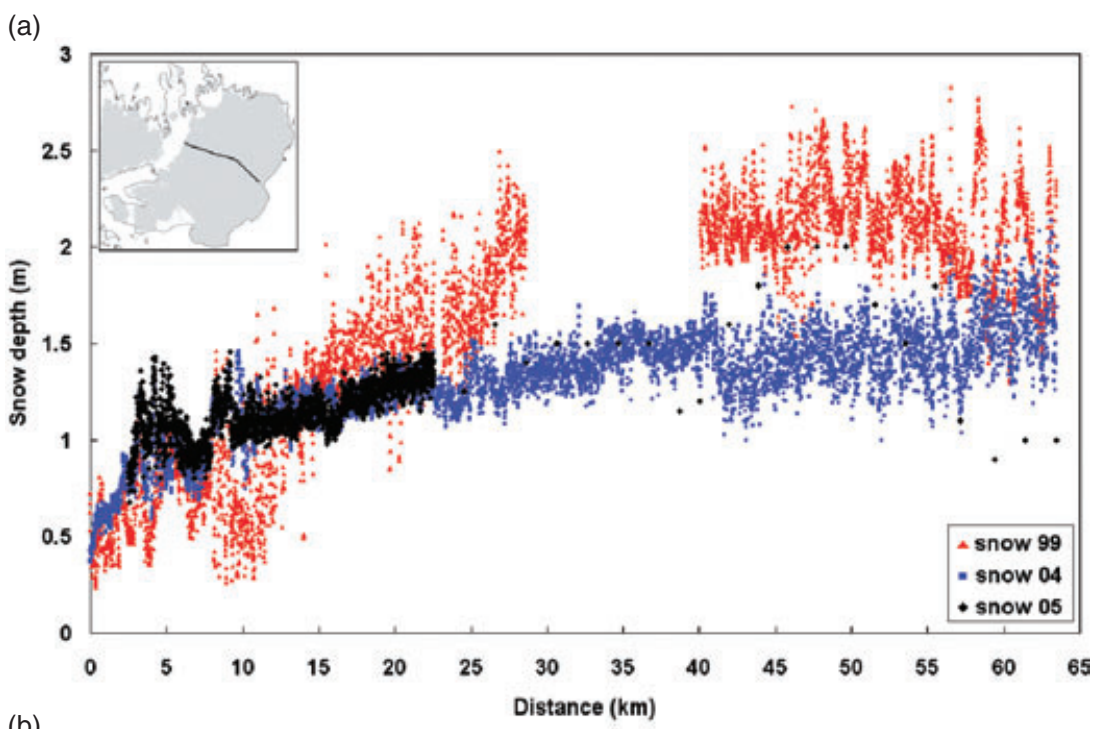

(b)

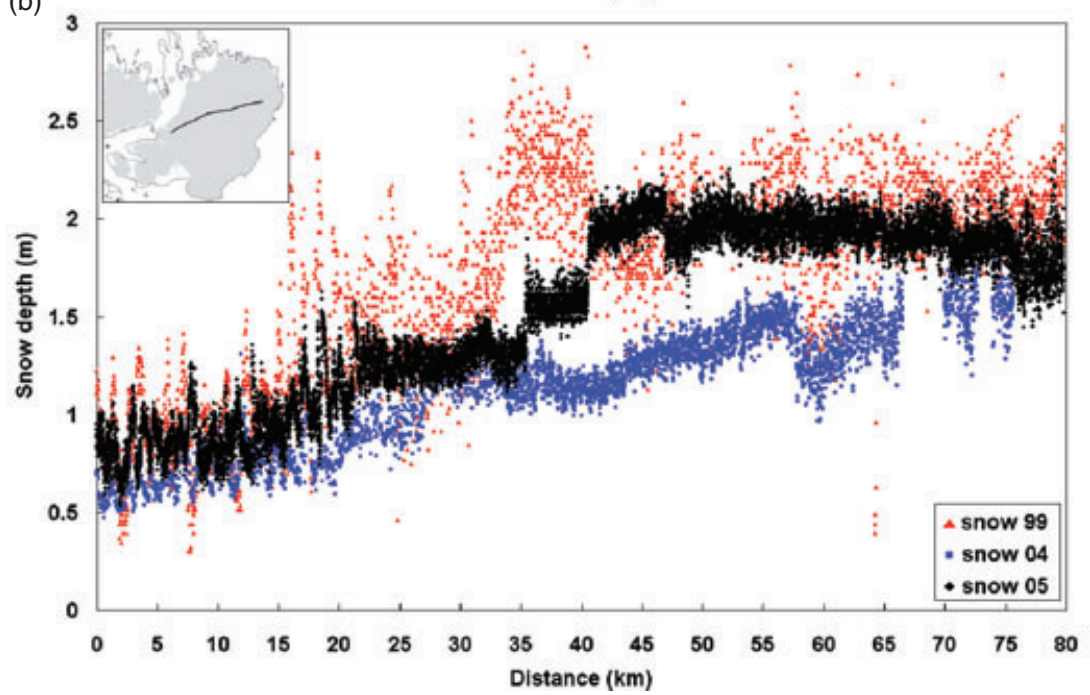

Figure 2 Snow thickness profiles along the (a) north-west-south-east and (b) south-westnorth-east transects on Austfonna. and $a_{0}-a_{3}$ are the coefficients determined using regression analysis. This procedure is performed by using the 1999 and 2004 data to train the model, and then using the 2005 data as an independent test dataset to evaluate the analysis. To take the considerable year-to-year variations in snow accumulation into account, snow thickness values need to be scaled before the regression coefficients are determined. We use the average thickness as a scale for the snow thickness such that the spatial average of the scaled values $s^{\prime}$ across the ice cap equals one $\left(\bar{s}^{\prime}=1\right)$. Thus, local values represent proportions of the average accumulation that vary between individual years, but the year-to-year variation in the scaled values is removed. The values of a determined using the 1999 and 2004 datasets individually are listed in Table 1. Average values of $a$ are used to describe the typical snow distribution, which is also evaluated independently using the 2005 dataset (also presented in Table 1). The correlations between the modelled and the observed values of snow thickness are high for the calibration, as well as for the validation datasets, yielding correlation coefficients larger than 0.8. An accumulation index map derived by this method is presented in Fig. $3 \mathrm{~d}$ and shows the spatial distribution of the scaled snow thickness.

\section{Discussion and conclusions}

Across Austfonna the snow distribution is largely controlled by two factors: the distribution of precipitation and the redistribution of snow by wind drift. From theory, one would expect both mechanisms to be controlled by terrain characteristics such as slope, exposition and elevation, in addition to the prevailing wind direction and 
Figure 3 Distribution of snow thickness measured along profiles in (a) 1999, (b) 2004 and (c) 2005; units are in metres. (d) Accumulation map derived from these measurements; the values are dimensionless and scaled to the mean snow thickness.
Figure 4 Scatter plots illustrating the relationships between (a) the measured snow thickness, $s$, and elevation, (b) $s$ and the $x$ coordinate and (c) $s$ and the $y$ coordinate. (d) Correlation between the measured snow depths and the values provided by the multiple regression function. The plots show data from 2004.
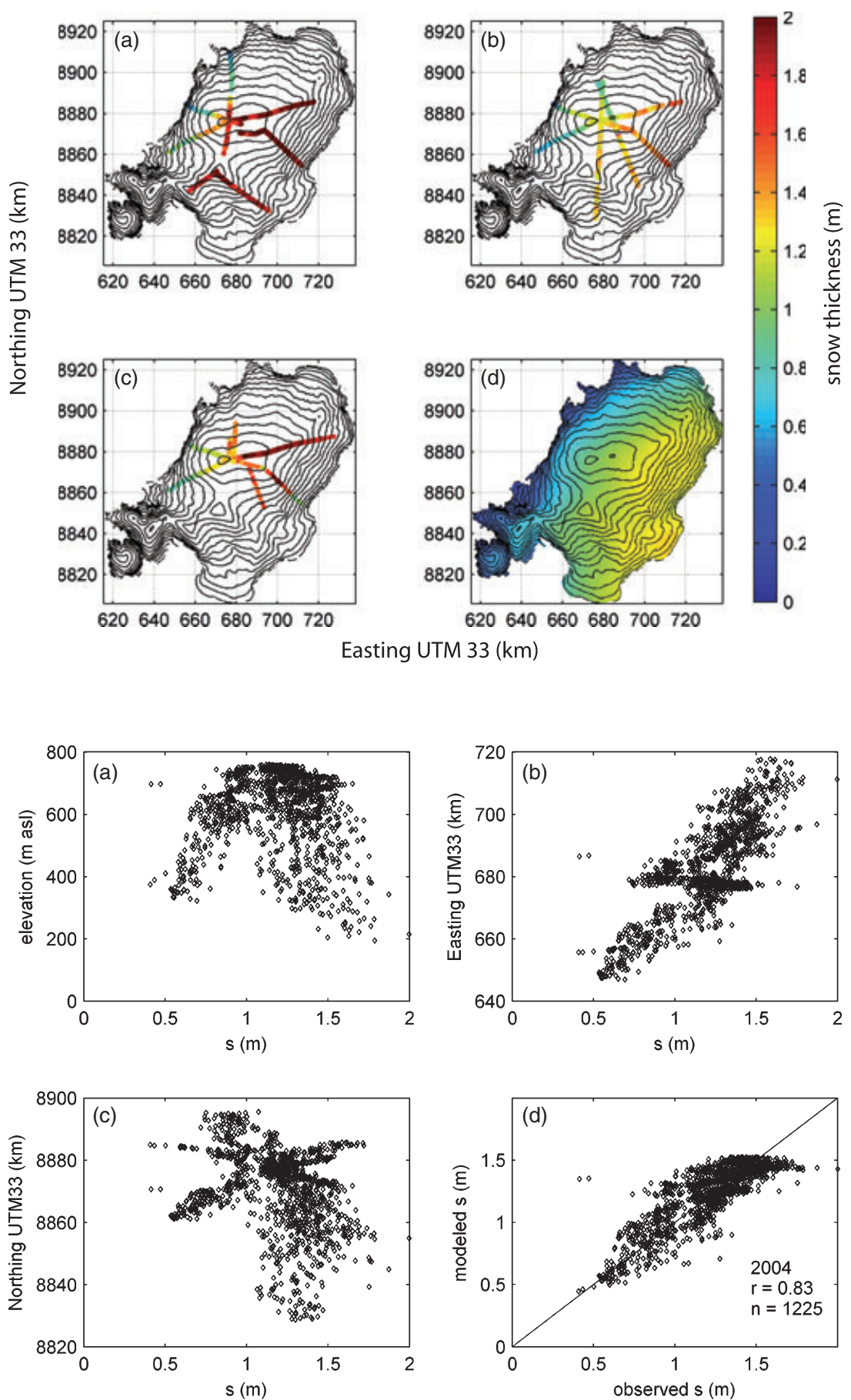

Table 1 Coefficients used to describe the snow distribution across the Austfonna ice cap and correlation coefficient $r$ between the modelled and the observed values along the radar transects.

\begin{tabular}{lllll}
\hline & $a_{1}(\mathrm{~m})$ & $a_{2}(-)$ & $a_{3}(-)$ & $a_{4}(-)$ \\
\hline 1999 & 86.2476 & $1.30 \times 10^{-5}$ & $-1.07 \times 10^{-5}$ & $1.1 \times 10^{-3}$ \\
2004 & 52.9529 & $1.16 \times 10^{-5}$ & $-0.68 \times 10^{-5}$ & 0.88 \\
Mean & 69.6003 & $1.23 \times 10^{-5}$ & $-0.87 \times 10^{-5}$ & 0.83 \\
2005 (evaluation) & - & - & - & $0.8 \times 10^{-3}$ \\
\hline
\end{tabular}


distance from the moisture source. The two latter effects are not specifically accounted for in our approach, so we implicitly assume that the direction and the strength of the moisture flux are constant. This assumption is not a severe oversimplification of reality because precipitation on Nordaustlandet comes predominantly from the east (e.g. Førland et al. 1997), and the major moisture source in that direction is the ice-free part of the Barents Sea. Furthermore, relating snow thickness to coordinates instead of either slope or exposition requires that there is a close relationship between these terrain characteristics and position. Ideally, on a hemisphere, the exposition and slope of each point are sufficiently determined by its position. The simple dome shape of the Austfonna ice cap comes relatively close to this ideal, and this explains the success of our simple approach.

Analysing the spatial distribution of snow thickness across Austfonna for the three years 1999, 2004 and 2005 revealed that there is considerable year-to-year variability, but that the accumulation pattern across the ice cap is constant. Snow thickness along the radar profiles varied in all datasets from high values in the south-eastern parts of the ice cap to lower values in the north-western regions. This distribution has been successfully described using a linear regression model that uses the spatial coordinates as predictors. We have also investigated the distribution of the residuals between modelled and measured snow thickness and found that they are normally distributed, thereby indicating the validity of the linear regression model.

In our simple model, we assume two different gradients for snow distribution: one vertical gradient with elevation and one horizontal gradient in the $x-y$ plane. These can be represented as linear functions of the three Cartesian coordinates. Using Eq. 1, we implicitly assume that the effects of the predicting variables $(x, y$ and $z$ ) on the dependent term $(s)$ are additive and do not interact. This condition might seem restrictive. However, in additional experiments we have investigated the effects of including interaction terms in a stepwise procedure and concluded that these are negligible.

Unlike previous interpolations of snow data, our approach enabled the calculation of an accumulation index for every point on the ice cap. This will be of great benefit in future work focusing on the modelling of the surface mass balance of Austfonna, something which requires spatially complete accumulation information possibly controlled by external meteorological data. A further aspect of possible interest to the climate community is that the distribution of accumulation across Austfonna may be regarded as an integrative proxy for the distribution of winter precipitation in a region where meteorological observations are otherwise scarce.

\section{Acknowledgements}

This work was carried out with support from the Cryosat Calibration and Validation project (ESA contract no. C90118), from SPICE, Space Borne Measurements of Arctic Glaciers and Implications for Sea Level (EU contract no. EVK2-2001-00262) and from INTEGRAL, Interferometric Evaluation of Glacier Rheology and Alterations (EU contract no. SST3-CT-2003-502845). The authors wish to thank the two anonymous reviewers, whose comments improved this article.

\section{References}

Aðalgeirsdóttir G., Gudmundsson G.H. \& Björnsson H. 2003. A regression model for the mass-balance distribution of the Vatnajökull ice cap, Iceland. Annals of Glaciology 37, 189-193.

Ahlmann H.W. 1933. The inland cartography of North-East Land. Geografiska Annaler 15, 47-68.

Bamber J.L., Krabill W., Raper V. \& Dowdeswell J.A. 2004. Anomalous recent growth of part of a large Arctic ice cap: Austfonna, Svalbard. Geophysical Research Letters 31, doi: 10.1029/2004GL019667.

Binney F.G. 1925. The Oxford University Arctic Expedition 1924. The Geographical Journal 66, 9-40.

Dowdeswell J.A. 1986. Drainage-basin characteristics of Nordaustlandet ice caps, Svalbard. Journal of Glaciology 32, 3138

Dowdeswell J.A. \& Drewry D.J. 1989. The dynamics of Austfonna, Nordaustlandet, Svalbard: surface velocities, mass balance, and subglacial melt water. Annals of Glaciology 12, 37-45.

Dowdeswell J.A., Drewry D.J., Cooper A.P.R., Gorman M.R. Liestøl O. \& Orheim O. 1986. Digital mapping of the Nordaustlandet ice caps from airborne geophysical investigations. Annals of Glaciology 8, 51-58.

Eiken T., Hagen J.O. \& Melvold K. 1997. Kinematic GPS survey of geometry changes on Svalbard glaciers. Annals of Glaciology 24, 157-163.

Førland E.J., Hanssen-Bauer I. \& Nordli P.Ø. 1997. Climate statistics $\theta$ longterm series of temperature and precipitation at Svalbard and Jan Mayen. DNMI Report 21/1997 Klima. Blindern: Norwegian Meteorological Institute.

Melvold K., Hagen J.O., Eiken T. \& Pinglot J.F. 1999. Report from fieldwork on the Austfonna ice cap, Svalbard, 7th April-7th May 1999. Oslo: Department of Physical Geography, University of Oslo. (Second year report of E.C. contract no. ENV4CT97-0490.)

Pinglot J.F., Hagen J.O., Melvold K., Eiken T. \& Vincent C. 2001. A mean net accumulation pattern derived from radioactive layers and radar soundings on Austfonna, Nordaustlandet, Svalbard. Journal of Glaciology 47(159), 555-566.

Punning Y.-M.K., Martma T.A., Tyugu K.E., Vaykmyae R.A., Pourchet M. \& Pinglot F. 1986. Stratification in an ice core from Vestfonna, Nordaustlandet. Polar Geography and Geology 10, 39-43 (translated from Materialy Glyatsiologicheskikh Issledovanii 52, 202-205). 
Schuler T., Fischer U.H., Sterr R., Hock R. \& Gudmundsson G.H. 2002. Comparison of modelled water input and measured discharge prior to a release event: Unteraargletscher, Bernese Alps, Switzerland. Nordic Hydrology 33, 27-46.

Schuler T.V., Hock R., Jackson M., Elvehøy H., Braun M., Brown I. \& Hagen J.O. 2005. Distributed mass balance and climate sensitivity modelling of Engabreen, Norway. Annals of Glaciology 42, 395-401.

Schuler T.V., Loe E., Taurisano A., Eiken T., Hagen J.O. \& Kohler J. In press. A calibrated surface mass balance model for the Austfonna ice cap, Svalbard, Annals of Glaciology 46.
Schytt V. 1964. Scientific results of the Swedish Glaciological Expedition to Nordaustlandet, Spitsbergen, 1957 and 1958. Geografiska Annaler 46, 243-281.

Watanabe O., Kamiyama K., Kameda T., Takahashi S. \& Isaksson E. 2000. Activities of the Japanese Arctic Glaciological Expedition in 1998 (JAGE 1998). Bulletin of Glaciological Research 17, 31-35.

Zagorodnov V. \& Arkhipov S. 1990. Studies of structure, composition and temperature regime of sheet glaciers of Svalbard and Severnaya Zemlya: methods and outcomes. Bulletin of Glaciological Research 8, 19-28. 